\title{
THE LIMITS OF A LABEL: FRAMING EASTERN ASIA'S TERRITORIAL CONFLICTS FOR A U.S.-AMERICAN AUDIENCE
}

\author{
Ethan Yorgason* \\ Kyungpook National University, 80 Daehak-ro, Buk-gu, \\ Daegu 41566, South Korea \\ E-mail: yorgason@knu.ac.kr
}

Published online: 25 January 2022

To cite this article: Yorgason, E. 2022. The limits of a label: Framing eastern Asia's territorial conflicts for a U.S.-American audience. International Journal of Asia Pacific Studies 18 (1): 1-29. https://doi.org/10.21315/ijaps2022.18.1.1

To link to this article: https://doi.org/10.21315/ijaps2022.18.1.1

\begin{abstract}
This article explores limits to the framing power of several important short terms and phrases typically used within eastern Asia's international politics. It conceptualises these labels as terminological frames. As frames, these terms/phrases help to set agendas, categorise, emphasise certain perspectives while excluding others from view, and ultimately shape opinions about controversial issues within international politics. Yet, I argue, the limits of frames have been insufficiently explored, especially as frames are taken to new audiences whose understanding of the broader discourses associated with the issues are weaker than that of the original audience. Do these terms still produce framing effects outside of eastern Asia? The study relied on a short survey of 800 U.S.-Americans. Respondents answered differing versions of questions relating to eastern Asian maritime politics in order to ascertain whether the wording and labels used affect evaluation of political issues. Specifically, the survey sought to determine whether use of East Sea vs. Sea of Japan, Northern Territories vs. Southern Kurils, and South China Sea vs. East Sea affected views of maritime disputes and issues relating to Korea, Japan, Russia, China/Taiwan, and Vietnam. It also explored whether an increasingly central phrase in eastern Asia's maritime territorial disputes- "inherent territory"-presented a stronger claim than other possible phrases claiming territory. Survey results showed no statistical difference through use of one term or label over another. Thus, a certain type of limit to the power of these terminological frames was found. Nevertheless,
\end{abstract}


the survey additionally demonstrated that producing framing effects required only a slight addition to the terminology, confirming the ease of framing international political issues to partisan effect.

Keywords: East Asia, territorial disputes, framing, discourse, toponyms

\section{INTRODUCTION}

Terminological contests pervade eastern Asia's territorial and maritime disputes. ${ }^{1}$ Apart from the content of claims between states to lands and seas, the words used to identify and describe those claims are often controversial. Terminology itself is even at the heart of certain disputes. Partisans not only yearn for their audiences - people both within and outside the debates themselves - to understand their political points, but they also strive to describe these points in the most effective - and sometimes what they regard as most "correct"- ways. For instance, how does one label the two virtually uninhabitable islets located nearly halfway between Korea and Japan (Dokdo, Takeshima, Liancourt Rocks)? And what is the sea they lie in (East Sea, Sea of Japan)? These and many other examples illustrate the importance of labels and descriptors within eastern Asia's international politics.

This significance is not surprising since well-deployed words relating to territory (such as "South China Sea" or "our inherent territory", for two more examples) load considerable rhetorical power into small terminological packages. Most directly, they imply or specifically claim a special relationship, by one group of people rather than others, to certain features and spaces on the earth's surface. In doing so, they support the typical function of territorialisation in modern life: dividing the world into discrete, nonoverlapping spaces controlled by various nation-states (Winichakul 1994; Vollaard 2009; Elden 2010a, 2010b). But these labels also do more. They stand in for historical relationships and ossify specific historical memories. They represent national virtue and convey nationalistic ambition. Some symbolise a state's role within the modern world. They may even partially define states' possible future actions within international relations (Agnew 2009; Roszko 2015; Yorgason 2017). In other words, these strategically utilised and often contested expressions - ones we might call (territorial) terminological frames - powerfully refer to and help structure wide-ranging discourses within international relations.

This study explores the power of these terminological frames. It operates through the lens of critical geopolitics, a sub-discipline of political geography 
closely connected to the somewhat better-known subfield of constructivism within international relations. These fields generally regard international politics' words, frames, and discourses as highly significant. Many studies seek to identify and analyse how specific frames have been employed within political contests, all the while assuming that framing has important effects, especially to those most directly affected by the struggles. However, I want to partially problematise that assumption. This project explores certain limits to these terminological frames' power. Most particularly, it turns attention away from how these terminological frames resonate within partisan contexts. Instead, it asks whether the frames affect viewpoints of relatively noninvolved outsiders, especially in situations where the frames are minimally explicated. Does the simple use of the term "Northern Territories" rather than "Southern Kurils" influence U.S.-American views of the territorial dispute between Japan and Russia, for example?

The main empirical tool I use to explore such questions is a relatively simple survey of 800 U.S.-Americans. Differing versions of basic questions about eastern Asia's territorial and maritime conflicts facilitate interrogation of terminological frames' capacity to affect respondents' understanding. Before discussing the survey further, however, the article first considers the relationship between frames and discourses within critical geopolitics and other allied fields to develop the concept of terminological frames and clarify which framing effects the study is looking for. I then introduce the specific terminological frames analysed. Next, the paper identifies the general research strategy, followed by carefully describing the survey. Results are summarised thereafter. One key finding is that few to no framing effects were associated with simply mentioning the terminological frames themselves. However, a second key finding, as the ensuing discussion and conclusion emphasise, is that framing effects are still easily produced; only minimal additional framing is needed to wield significant effects.

\section{ANALYSIS OF TERMINOLOGICAL FRAMES}

This research analyses aspects of eastern Asia's terminological frames from the viewpoint of critical geopolitics. Geopolitics has been since the late 1800 s - though not without controversies, near-deaths, and revitalisationsthe subfield of political geography most closely aligned with political science's international relations. It traditionally concerned itself with theorising contests over territory, colonies, and resources between (usually powerful Western) 
states. In the 1980 s, critical geopolitics emerged in part due to concerns that this focus operated too much in the service of state power. The subfield built partly from (typically semi-Marxist) political-economy perspectives within geography, but by the 1990s gravitated towards poststructuralist tools, including discourse analysis, in efforts to deconstruct geopolitical power. Thus, the scholarly goal shifted for critical geopolitics, as for many constructivist perspectives elsewhere, from helping states amass geopolitical power to understanding and often contesting such power.

The current project joins a small but growing literature exploring eastern Asia's maritime territorial conflicts within critical geopolitics. ${ }^{2}$ Three recent articles in this literature deserve a particular mention. First, Christian Wirth (2016) shows how states use conflicts often understood through specific dominant geopolitical discourses over and within East Asian seas to secure three types of state power: economic/developmental, national unity, and position within the world's East/West "civilisational" divide. Next, Ethan Yorgason (2017) charts how discourses associated with eastern Asia's major territorial disputes reinscribe state powers that might otherwise erode within globalisation. And third, Simon Wellisch and Lukáš Laš (2020) quantitatively argue that English-language newspapers within Japan reproduce rather than question the Japanese state's intransigent approach to territorial disputes. Each article applies discourse analysis to eastern Asia's territorial disputes, though in varying ways. Wirth points to how the conflicts both follow and strengthen a few key broad discourses, Yorgason analyses at more of a meso-level in identifying common discursive patterns in states' actions, while Wellisch and Laš determine the frequency of important terms and collocations through a micro focus. These variations show that discourse analysis is not a single method that is simply applied. Instead, as becomes even clearer shortly when adding framing to the picture, it encompasses multiple types of and various levels of discourse.

The present research extends the concerns of these three articles in both broad subject matter and use of discourse analysis. Perhaps most importantly, it gives stronger attention to framing - which these three articles could potentially have done but did not - by centring it as the key substantive and methodological concept. The remainder of this section lays out how this project conceives of and uses framing/framing analysis, especially in relation to discourse/discourse analysis. It draws particularly on constructivist political research, including that done within critical geopolitics.

Discourse analysis and frame analysis are common within constructivist scholarship. However, relationships or differences between the two concepts 
are often ambiguous, with even some conflation of the two types of analysis (van Dijk 2016a). Sometimes, for example, it seems that frames organise discourse (Luukkonen and Sirviö 2019: 17-18; Walsh 2014: 318); for other research, frames utilise or result from discourses (Holden 2020; Wang 2017; Wiegand 2005: 349). Put slightly differently, some scholars see frames as constraining discourse (Zellman 2015: 493; Zacher et al. 2014: 32), while others argue that discourse constrains frames (Sanderfer 2016: 133). Or perhaps both relationships exist; frames in this sense are subsets of discourses, ones that help to create discourses, while simultaneously resulting from discourse (Sanderfer 2016: 133; Walsh 2014: 318; Wang 2017). For this study, I regard frame analysis as a subset of the larger category of discourse analysis (Hope 2011: 1). That is, I understand discourses to encompass but exceed frames. Frames, in the first instance, result more from discourses than discourses result from frames. Nevertheless, frames may recursively affect the broader discourses. Given this understanding, discourse analysis is a field studying a wide array of both strictly communicative and broad social practises. These practices allow people to produce some types of social discussions rather than others, with certain meanings both being made intelligible and foregrounded. ${ }^{3}$

Within discourse analysis, framing plays a fundamental part, especially by foregrounding certain meanings over others, though also through simply making meanings intelligible, a point I return to later. For Teun van Dijk, a leading voice with: in discourse analysis, frames are definitions of situations, or perhaps more broadly the interpretation schemas through which people understand those situations (2016a: 4, 16). Also, elsewhere, van Dijk (2016b: 4-5) refers to Charles Fillmore's (1976: 20, see also 25-29) version of frames, a definition that is useful here: "the appeal, in perceiving, thinking, and communicating, to structured ways of interpreting experiences". Among other things, frames organise cognition such that when certain words are used, the process of interpretation activates whole sets of socially organised knowledge beyond the putative definitions of those words. Thus, the term "China" summons various assumptions, understandings, and implications as a political frame, depending at least partly on the discursive context. These conscious and less-than-conscious thoughts that have been both invoked and evoked may involve, among others, ideas about governmental structure and type, historical influence, colonial experience, ethnic/racial content, nationalism, human rights, and potential futures. China as a frame thus creates intertextual linkages (Purcell et al. 2017) that reach far beyond any simple and basic definition of the term itself. 
International relations literature describes and conceives of frames in many ways, pointing to a multifaceted concept. Whether in verb or noun form, "frame" occasionally substitutes colloquially for terms such as "portray", "represent", "interpretation", or "perspective" (for example, Holden 2020; Kim 2017; Wilde 2004; Purcell et al. 2017; Walsh 2014; Wang 2017; Burrett 2014). Additional frequently used synonyms and metaphors include "mental model", "imaginary", and "meaning system" (Luukkonen and Sirviö 2019: 1718); "judgment modes" (Maoz et al. 2007: 82); "mental filters" and "building blocks of cognition" (Hussein 2017: 83); "narratives" (Zellman 2015: 493); focusing devices such as a "lens" (Zacher et al. 2014: 31; see also Pain 2015) or a bounding mechanism (such as a picture frame) that simultaneously limits which aspects are seen in a situation and focuses on/centres some of those elements above others (Sage 2008; Leitner and Strunk 2014).

In addition to the definitional variety, scholars also find frames to operate at various levels of generality. Mat Hope points to primary frameworks as the highest level of generality, or the most basic level of understanding (Hope 2011; see also Goffman 1974; Hussein 2017). Metaframes operate at various intermediate levels (on metaframes, see also Luukkonen and Sirviö 2019), while issue frames work at more specific levels. Thus, on the one hand, primary frameworks shape deep and broad social inclinations, while on the other, issue frames connect to one or a few issues. The former more often operate at sub-conscious levels while the latter are typically easier to identify and influence. This variation likely leads scholars to emphasise different ways frames are established and discerned. Many researchers emphasise framing's intentionality (Goddard 2009; Sanderfer 2016; Maoz et al. 2007; Zellman 2015). For them, framing is a type of strategic representation to establish certain points of view. Other writers emphasise more perceptual processes. One possibility in this regard involves ascertaining both how (and the meanings that result when) individuals and groups come, without much overt awareness, to structured interpretations of social situations (for example, Luukkonen and Sirviö 2019). In a second, related version, framing analysis involves scholars abstracting a population's fundamental cognitive structures, ones that are often unacknowledged or poorly understood (for example, Olarte-Olarte 2019). Taking this impulse further, a third version regards frames less in terms of cognition and more as the total social circumstances through which societies operate. For Inwood and Bonds, for example, U.S. society's ongoing practises are structured through the frame of settler colonialism (deriving from historical inclinations and experience) (Inwood and Bonds 2016). 
Nonetheless, despite different accentuations, scholarship revolves around the sense that frames draw out certain interpretative tools and content rather than others in any given situation. For Hussein, "frames are complex cognitive, perceptual, and meaning structures which individuals impose on [the] information environment and with the help of which they operate in the construction of the meaning of realities" (2017: 83). For example, a nationalist framing of a territorial conflict shapes interpretation through nationalist points of reference, such as victimisation and ethnic mistrust, rather than other, perhaps more conciliatory coordinates (Wiegand 2005). So, while not fully consistent with each other, the literature's modalities highlight framing's various operations and effects.

Among these effects, classification, emphasis, and exclusion are central (Hussein 2017: 84-85). Some frames shape which things seem to be related or unrelated, for example (Pain and Staeheli 2014), while others push towards seeing social-political possibilities as (perhaps artificially) binary through either-or categorisation (Mitchell 1990; Jones 2012). More generally, framing's categorisation often powerfully obscures (or skilfully emasculates: Goddard 2009) alternative interpretations. Through emphasis and exclusion, frames possess tremendous agenda-setting capacity (Burrett 2014). Well-established frames set the terms for what likely will or will not be said in the future about certain issues (Zacher et al. 2014). Experimental framing research demonstrates that carefully crafted frames influence people's political viewpoints (Maoz et al. 2007; Zellman 2015).

It is no wonder, then, that partisans so strongly emphasise and contest certain terminology within eastern Asia's international politics, such as the terms mentioned at the outset of this article. In this eastern Asian context, usage is often intentional and powerful. These short phrases can be considered issue frames, as they are narrowly defined and often utilised strategically. They typically connect to wide-ranging, specific, and well-developed discourses. It makes sense to describe them as terminological frames.

However, this article asks a question involving these terminological frames that has been insufficiently addressed. What happens when they move from their original environment to a secondary audience, one less attuned to the larger discourses they connect with (Murphy 2010: 769-772; Roszko 2015: 235)? Can framing effects be found? Goddard suggests that frames, like all discourse, can be multivocal, that is, simultaneously communicating differently with different audiences (Goddard 2009). Her research applies the idea to situations of fully disclosed frames. However, I want to explore multivocality when frames are much more minimally expressed. Can a 
less-fully aware audience also pick up and respond to the subtle signals of framing? Can this framing produce responses like those it elicits in its primary surroundings?

\section{TERMINOLOGICAL FRAMING OF MARITIME TERRITORIAL DISPUTES IN EASTERN ASIA}

The simplest framing elements used to advance an agenda are single key words and phrases. These appear as labels, such as names, or other carefully chosen descriptors. In eastern Asia's international relations, such framing occurs through many methods. The language used in the label is one. Should the islands disputed between China/Taiwan and Japan be called Diaoyu or Senkaku, for example? ${ }^{4}$ The choice can affect how the audience understands which country the islands belong to. In addition, qualifiers, the lack of qualifiers, or the choice of qualifiers may also affect a situation's interpretation. These qualifiers might be part of a name, but they need not be. To take a case where the qualifier is part of a name, is it more appropriate to use the label "Taiwan" or "Taiwan, China"? Several such cases of small terminological and descriptive differences exist in eastern Asia. Many are strongly contested and controversial since partisans expect these terminological frames to assist or damage their causes. I cannot study all these important terminological frames here. But I explore a few significant ones relating to maritime territorial conflicts, chosen in part due to my prior research on these disputes.

The cases are of two types. First are terminological frames in the form of alternative toponyms. These relate to appropriately labelling or naming certain features of the earth's surface. Nearly 50 years ago Andrew Burghardt (1973: 9) noted that nation-states are jealously protective of place names, particularly when these toponyms reflect a state's (especially historical) "grandeur". Though often rooted in the past, the politics of naming are present-centred, as toponyms possess the power to both include and exclude as well as to centre and marginalise certain narratives, histories, or peoples, etc. (Whelen 2011). Thus, toponyms are often key to contests over past or present colonial relationships (Murphyao and Black 2015; Ryu 2012). This project uses three toponymical cases: the East Sea versus the more frequently used Sea of Japan, the Northern Territories versus the Southern Kurils, and the East Sea versus the more common South China Sea.

The water separating Japan from Korea (as well as the south-eastern edge of mainland Russia) is currently most often labelled internationally 
the Sea of Japan. South Koreans call it the East Sea. ${ }^{5}$ Colonialism helped its name become embroiled in the Korea-Japan rivalry. South Koreans generally argue that prior to colonialism (effectively about 1905-1945), no single conventionally accepted name of the sea existed, though Sea of Japan and East Sea were among the more popular monikers. But the adoption of Sea of Japan by the International Hydrographic Association, establishing it as the globally accepted name, happened in 1929 when Korea could not effectively protest. As such, many South Koreans argue, Sea of Japan not only erases a more complex history but also represents the continuing spoils of Japan's colonising. The label may even encourage belief internationally that the sea somehow is connected most strongly or perhaps belongs to Japan (The Society for East Sea 2014; Yi 2014; Voluntary Agency Network of Korea n.d.; Johnson 2017). Japan counters that the conventionalising process legitimately followed international standards; thus, there is no need to rethink the name. Doing so, some Japanese argue, introduces needless confusion into navigation and world knowledge as well as recklessly denies settlements already made between Japan and South Korea over colonialism (The Ministry of Foreign Affairs of Japan 2017; The Government of Japan 2019; Hydrographic and Oceanographic Department, Japan Coast Guard n.d.).

The dispute between Russia and Japan over the Southern Kuril Islands/ Northern Territories relates somewhat less to the name per se, and more to ownership. The countries contested the Kuril island chain northeast of Hokkaido, along with Sakhalin, in their growing late 19th century rivalry during their territorial expansions. Although population and effective state control were low during this period, Japan took the upper hand militarily and in international law. World War II reset the relationship in favour of Russia. After the Japanese surrender, the Soviet Union claimed both Sakhalin and the Kurils. Japan acceded to this result except for the four small islands/islet groups closest to Hokkaido in the northeast where the Japanese presence was strongest, islands it calls its Northern Territories. The continuing territorial dispute is the most significant reason that a post-World War II peace treaty between the countries remains unsigned. Diplomatic efforts to reclaim the islands for Japan have continued since nearly the end of the war. Prospects of settling the dispute have waxed and waned in multiple cycles. A significant issue is that while the Soviet Union signalled possible willingness to turn over two of the four territories (Habomai Islands and Shikotan; the signals from the post-Cold War Russian Federation have been weaker), Japan insists on the return of all four (Goodby et al. 1995; Schoenbaum 2008; Bukh 2010). 
The international label for the sea south of China and east of Vietnam is not contested vigorously at present. Vietnam seems little interested in seriously challenging the hegemony of "South China Sea". Nevertheless, Vietnam occasionally reminds audiences outside its borders that it calls that body of water the East Sea. International commentators sometimes also note that fact. More fundamentally disputed, however, are several small islets and islet groups within the sea. These territorial wranglings, along with attendant claims to maritime control permitted under the United Nations Convention on the Law of the Sea, involve China/Taiwan, Vietnam and a few other states. In combination with China's somewhat ambiguous promotion of its "ninedash line", the situation leads to international uncertainty over whether China is increasingly claiming ownership over this sea that partly bears its name (Amer 2014; Vu 2020; Ives 2017).

The second type of terminological framing analysed by this paper involves qualifying terminology in claims to territory. Eastern Asia's territorial disputes have generally risen in prominence through the past several decades. Attention to the terms used to make those claims has likewise increased. The simplest territorial claim is that a particular piece of land "is (our, Korean, Vietnamese, Chinese, Russian, Japanese, etc.) territory". But many statements add adjectives/adjectival phrases to this basic formulation, presumably to increase its persuasiveness. Thus, "historical", "by international law", "traditional", "sacred", "natural", "inviolable", "inalienable", "ancient", and many other terms are added to qualify "territory".

Over the decades, a particular phrase seems to have achieved special priority in this regard: "inherent territory" (as in "our inherent territory", "inherent Japanese territory", etc.). Partisans use the phrase most often in Japanese (固有の領土), Chinese (固有領土), and Korean (고유 영토), but it also is prominent in their English-language pronouncements. It emerged in the 1940s but especially in the 1950s as a common phrase within Japanese claims to the Northern Territories. Then, as the Takeshima/Dokdo conflict with South Korea became sharper in the 1960s, as did the Senkaku/Diaoyu conflict with China/Taiwan in the 1970s, the term began to appear in connection with these disputes as well. By the 21st century it was a well-established mantra for all three claims, whether expressed officially or by civilians. In reaction, apparently, South Korean and Chinese responses began incorporating the same phrase. This counter-usage was not as strong as from Japanese supporters until the 2010s, however. It only became the People's Republic of China key phrase in that decade as it was applied not only to the Diaoyu/Senkaku 
dispute but also to claims over the South China Sea islets. The phrase's use in South Korea has never been as profuse, but it does appear occasionally in claims to Dokdo. Thus, I give "inherent territory" special attention here partly because of its significant role in eastern Asia's territorial disputes. In addition, however, the phrase is also interesting since this research involves an Englishspeaking audience. "Inherent territory" is a curious phrase in English; it seems to introduce more ambiguity than precision into discussions. It is not at all clear what it most specifically connotes, though those using the term clearly intend it to bolster their rhetorical influence (Bukh 2010: 49-72; Wada 2013: 31-43; Okuda 2014: 61-72; Lee 2015: 131; Yorgason 2018). This study tests the framing's presumed persuasiveness.

\section{RESEARCH STRATEGY AND THE DYNAMICS OF FRAMING}

This research assesses whether the terminology identified above produces "framing effects" (shows signs of resonating and activating framing's intertextual knowledges) beyond the communities in which the terms emerged. Does use of Sea of Japan on the one hand, or East Sea on the other, bias the views of people outside of eastern Asia towards political situations connected to that sea? Does this audience find a claim of a country's "inherent" territory more powerful than alternative phrasings?

Worldwide research to test this issue would have been ideal. But given that impossibility, I designed the survey used here towards U.S.-Americans. This is an important audience within global politics. U.S.-Americans reside within the world's most powerful state (though less hegemonic than it once was), the country that most strongly shaped international political assumptions and expectations over the past several decades. Perhaps more consequentially for present purposes, this audience is also relatively ignorant towards eastern Asia's maritime territorial issues. While the U.S.A.'s alliances may incline U.S.-Americans towards favouring certain countries, they are not partisans, strictly speaking, as average U.S.-Americans presumably know very little about eastern Asia's maritime and territorial disputes. Without many preconceptions, their survey responses likely measure framing's impact quite directly. In addition, since U.S.-Americans use English, the most common language in international politics, their answers may also provide an important, if imperfect, indicator of the territorial terminological frames' power within international discourse. 
The survey attempts to ascertain framing effects under two conditions: (1) a relatively uninvolved audience, and (2) relatively minimal expressions of potential frames. Two quite different framing experiments on Israeli audiences help set expectations for this U.S.-American audience. First, Maoz and colleagues found that situations of ambiguity produce greater framing effects: "issues or options about which there is higher consensus are less susceptible to framing" (Maoz et al. 2007: 88, see also 83; see also Maoz et al. 2002). When higher uncertainty exists, shifting the frame can have a stronger impact than when people already have strongly formed opinions. Therefore, given U.S.-Americans' lack of knowledge of the political conflicts explored here, even relatively minimal framing could be powerful. Second, Zellman argues that framing works best when culturally resonant: "popular susceptibility to framing effects is substantially limited by deeply ingrained societal beliefs and values". Effects rise when frames connect to well-developed discourses (2015: 503, see also 493-494; see also Benford and Snow 2000; Entman 2008). Put slightly differently, frames have more weight when audiences have the background to easily make sense of and agree with them. Thus, without enough connection to meanings significant to the audience, intended frames may be ineffectual. In this sense, the framing in the present survey may have difficulty creating significant effects. While this study is not designed to directly test these processes, they are drawn on below to help interpret survey results. ${ }^{6}$

\section{THE SURVEY}

This study's very short survey queried 800 respondents. It made use of the Google Forms survey tool and was distributed 17th to 23rd April 2020 via Amazon's Mechanical Turk (MT). A random survey of U.S.-Americans would have been ideal, but resources for that were unavailable. Nevertheless, I attempted to make the sample as random as possible within MT's constraints. MT's online tasking system pays respondents to take surveys. It allows respondents who meet certain criteria to accept and complete the surveys on a first-come first-served basis. Other than requesting respondents who had proven reliable at other MT tasks, I specified only U.S. citizenship as well as a 20 -years-old age minimum to clearly target post-high school ages. I advertised that respondents would answer a short questionnaire on international issues, with no special expertise necessary. The objective was to obtain a somewhat representative sample of ordinary adults in order to see how different framing options are commonly interpreted. 
Unfortunately, as mentioned, those who chose to take this survey through the MT platform do not represent U.S.-American adults perfectly. As self-reported, based on the survey's demographic questions, men were overrepresented (61\% of respondents). So too were people their $20 \mathrm{~s}$ and $30 \mathrm{~s}$ (68\% higher in comparison to the overall U.S. population), while Americans above 50 years old were underrepresented (58\% lower). However, a chi-squared test showed respondents were distributed within geographic regions in accord with the overall U.S. population. ${ }^{7}$ Next, $37.6 \%$ of respondents considered themselves liberal/progressive politically (likely a slight overrepresentation), with $31.8 \%$ and $30.6 \%$ claiming to be moderate and conservative, respectively. On the other hand, $11.6 \%$ had no more than a high school degree, $18.3 \%$ had taken some post-high school courses without earning a bachelor's degree, $52.4 \%$ earned a bachelor's degree as their highest degree, and $17.8 \%$ earned a post-graduate degree. Thus, the sample deviates from U.S. population averages, in some ways more than others. Nevertheless, while the sample does not represent U.S. society perfectly, it likely comes closer and tells us more than many types of samples frequently utilised in experimental framing/ cognitive research, such as opportunity (i.e., a university classroom), snowball, or even artefactual (targeting participation from certain groups) (Maoz et al. 2002; Maoz et al. 2007; Zellman 2015). In addition, I would argue, the impact of the divergences is unclear. These demographic differences do likely affect the broad answers to each major question. The relative lack of Cold-War memories due to youth, the predominance of men, and the high education, for example, might reasonably affect respondents' foreign-policy attitudes. However, this study is not centrally interested in those broad answers; rather it prioritises the framing effects that differently framed versions of the major questions explore. It is more difficult to specify how or why the demographic disparity between the study's sample and the U.S. population might impact these effects. ${ }^{8}$ Nevertheless, it should be kept in mind that the study does not draw on a true random sample.

As noted, the study is not concerned with respondents' actual answers to the questions, either as individuals or demographic groups; instead, via $T$-tests, it compares answers across variations of the same questions using different terminological frames. Respondents answered four basic questions about eastern Asia's international relations. However, each question was one of four possible versions of the question. Each question incorporated terminological frames in two places. Each location alternated between two variations of the frame. With two places holding terminological frames and two alternatives for each place, every question had four versions. The survey 
randomly assigned respondents one version of each question (randomised independently of prior questions). Thus, each respondent took one of $256\left(4^{4}\right)$ version paths through the four questions.

All questions relate to actual, relatively recent incidents and at least subtly connect to U.S. foreign-policy concerns. One version of Question 1 appeared as follows on the survey:

Japan asks for return of Northern Territories. The small islands sit just northeast of Japan's Hokkaido Island and at the southern edge of Russia's Kuril Islands. The Soviet Union claimed them after Japan's World War II surrender. The islands "are historic Japanese territory", the Japanese government asserts.

Do you support a U.S. diplomatic statement encouraging Russia to return the islands to Japan?

The first sentence's bolded type was part of the survey, but the italicisation was not. The italicisation here shows where territorial frames differed in differing versions. Half of the versions replaced "Northern Territories" with "Southern Kurils", and half employed "inherent" rather than "historic". Thus, Question 1A used the Northern Territories/historic pairing, 1B: Southern Kurils/historic, 1C: Southern Kurils/inherent, 1D: Northern Territories/inherent. Variation in the italicised terms likewise gave Question 2 four versions:

Japan and China spar over small islands. China called on Japan to return several small islands located close to both the Okinawa Islands (Japanese territory) and Taiwan (claimed by China). China asserts the islands were stolen during Japan's 19th-20th century imperial expansion. The islands "are inherent Chinese territory", says the Chinese government. Japan counters that it claimed the uninhabited islands legitimately under international law.

Which country should the islands belong to?

For this question, "Chinese" alternated with "Japanese" for one variation. For the other, two versions used "inherent", and two omitted any adjective preceding "Chinese" or "Japanese". Additionally, for those using "Japanese", the sentence order of the main paragraph after the "China asserts ... imperial expansion" sentence was modified to read: 
Japan counters that it claimed the uninhabited islands legitimately under international law. The islands "are [inherent] Japanese territory", says the Japanese government.

Like Question 2, Question 3 asked respondents which country's territorial claims they support. It again alternated between "inherent" territory and another option: "originally". But rather than giving more space to one country's argument over the other, as in Question 2, its second framing device was the sea name.

China and Vietnam trade accusations in South China Sea. A Vietnamese fishing boat sank after colliding with a Chinese naval vessel near a set of small islands claimed by both countries. No lives were lost, but each side accused the other of causing the collision and intruding illegally into its seas. Vietnam argues its fishers have used the islands for generations. China claims the islands are originally Chinese territory.
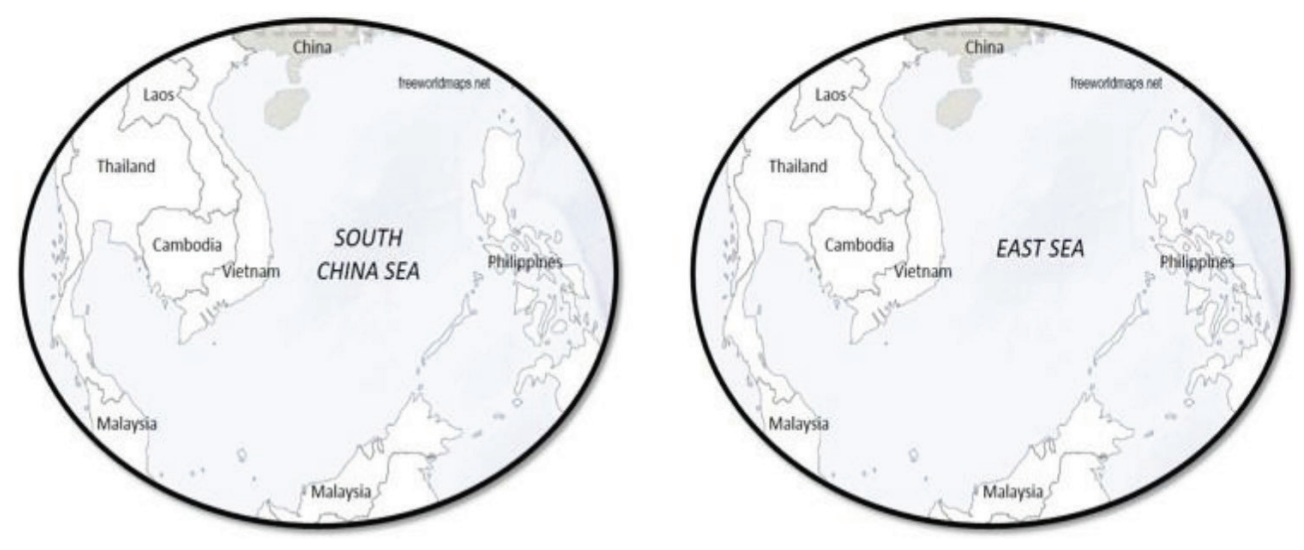

Which country's territorial claim would you likely support?

Figure 1: The two versions of the map used with Question 3. ${ }^{9}$

Here East Sea replaced South China Sea in two versions, both in the bolded introductory statement and on the map (as shown in Figure 1). Question 4 used a map and sea names similarly to Question 3 (as shown in Figure 2), but more directly asked about U.S. foreign policy outcomes. 

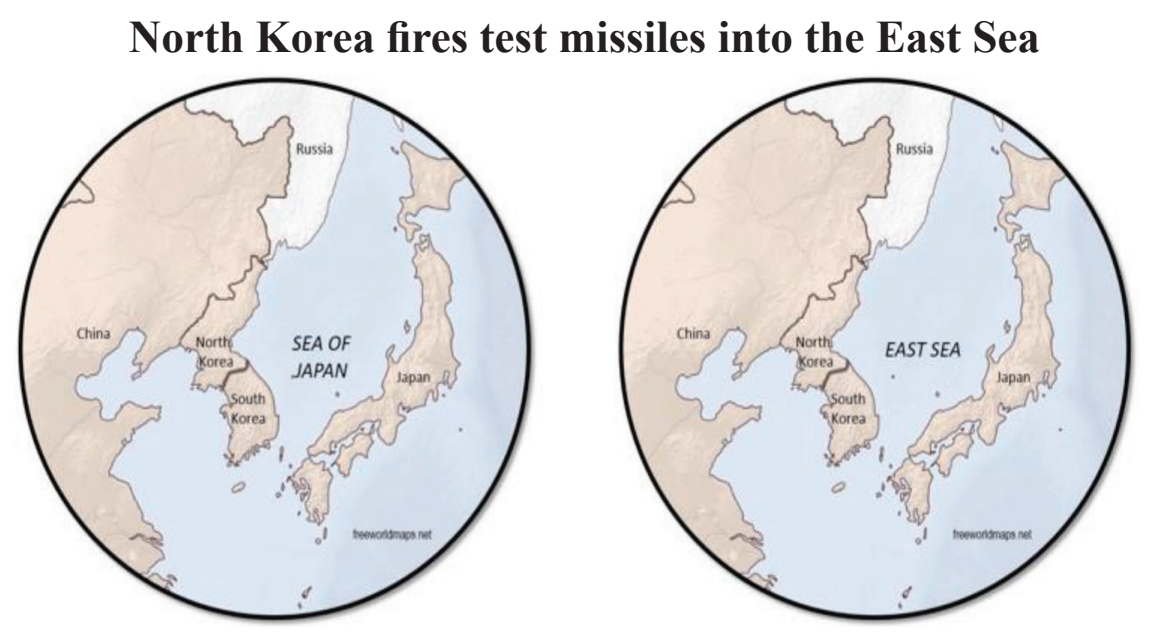

Do you support increasing spending on the U.S./South Korea alliance to better safeguard South Korea's security?

Figure 2: The two versions of the map used with Question 4.

Here, Sea of Japan alternated with East Sea while "Japan" rotated with "South Korea". Together, these four questions explore subtle framing effects connected to three maritime physical features: two seas (Questions 3 and 4) and an island group (Question 1). Given U.S.-Americans' expected relative ignorance, the questions test whether the labels affect notions of which state the island group belongs to and whether sea names convey a sense of ownership. The questions $(1,2,3)$ also probe whether labelling a territory as "inherent" strengthens the claim to it.

Most respondents likely answered the questions rapidly, as payment depended on completion of the survey rather time spent. ${ }^{10}$ Respondents answered questions from options I treated as a 7-point scale. For the two yesno questions ( 1 and 4 ), the choices were, from 1 to 7 , respectively: definitely not, probably not, maybe not, neutral, maybe, probably, definitely. For the questions about state ownership ( 2 and 3 ), the ascending scale ran: definitely China, probably China, maybe China, neutral, maybe Japan (for Question 2)/Vietnam (Question 3), probably Japan/Vietnam, and definitely Japan/ Vietnam. I initially suspected average answers for most questions would be near 4, given my sense of U.S. society - both as an U.S.-American and from my studies - that U.S.-Americans are likely to be either neutral and/or lack of knowledge of the questioned issues. Nevertheless, some of the questions have clear ties to U.S. foreign policy and alliances. Thus, answers for Questions 1 and 2 might be expected to lean towards Japan over China and Russia, for example, and the average answer might be relatively high for Question 4 in 
supporting U.S. allies against North Korea. Of course, the answers themselves are not the key concern here, as noted, but rather how the answers to various versions of the questions compare to each other. The existence of different responses between versions would suggest that framing effects were activated.

\section{RESULTS}

Table 1 shows survey results. The first column indicates which question version the row applies to. Every question had four versions (A to D), each with a different combination of framing terms, shown in the table's second column. The table also aggregates results when holding one terminological frame constant while the other varies. For Question 1, for instance, the two versions using "Northern Territories" (1A and 1D) were aggregated in order to compare to those using "Southern Kurils" (1B/1C). The third column shows the number of respondents who answered each version/aggregation. Ideally, each question version would have 200 respondents, with 400 for aggregations. The actual number of respondents differed somewhat due to the survey's randomisation procedure. The fourth and fifth columns give the average numerical score (again, varying $1-7$, with $4=$ Neutral) and standard deviation for each version/aggregation. Average responses tended towards neutrality, likely confirming that most U.S.-Americans do not have strong opinions on these questions. As also expected, the slight skewing away from neutrality follows U.S. foreign policy signals.

Table 1: Summary and comparative $T$-tests of the survey's question versions

\begin{tabular}{|c|c|c|c|c|c|c|c|c|}
\hline \multirow{2}{*}{$\begin{array}{l}\text { Question/ } \\
\text { aggregation } \\
\text { version }\end{array}$} & \multirow{2}{*}{$\begin{array}{c}\text { Framing } \\
\text { terms } \\
\text { used }\end{array}$} & \multirow[t]{2}{*}{$N$} & \multirow[t]{2}{*}{ Average } & \multirow[t]{2}{*}{$\mathrm{SD}$} & \multicolumn{4}{|c|}{$\begin{array}{l}T \text {-test statistic ( } p \text {-value) } \\
\text { compared to other versions }\end{array}$} \\
\hline & & & & & $\mathrm{B}$ & $\mathrm{C}$ & $\mathrm{D}$ & Combinations \\
\hline $1 \mathrm{~A}$ & $\mathrm{NT}, \mathrm{h}$ & 231 & 4.73 & 1.67 & $0.83(0.41)$ & $0.56(0.58)$ & $1.3(0.20)$ & \\
\hline $1 \mathrm{~B}$ & SK, h & 187 & 4.59 & 1.73 & & $0.27(0.79)$ & $0.42(0.67)$ & \\
\hline $1 \mathrm{C}$ & SK, i & 203 & 4.64 & 1.71 & & & $0.71(0.48)$ & \\
\hline $1 \mathrm{D}$ & $\mathrm{NT}, \mathrm{i}$ & 179 & 4.52 & 1.63 & & & & \\
\hline $1 \mathrm{~A} / 1 \mathrm{D}$ & NT & 410 & 4.64 & 1.65 & & & & $0.18(0.86)$ \\
\hline $1 \mathrm{~B} / 1 \mathrm{C}$ & SK & 390 & 4.62 & 1.72 & & & & \\
\hline $1 \mathrm{~A} / 1 \mathrm{~B}$ & $\mathrm{~h}$ & 418 & 4.67 & 1.69 & & & & $0.72(0.47)$ \\
\hline $1 \mathrm{C} / 1 \mathrm{D}$ & $\mathrm{i}$ & 382 & 4.58 & 1.67 & & & & \\
\hline $2 \mathrm{~A}$ & $\mathrm{i}, \mathrm{C}$ & 184 & 4.37 & 1.65 & $0.42(0.68)$ & $2.38(0.02)$ & $3.90(0.00)$ & \\
\hline $2 \mathrm{~B}$ & $\mathrm{n}, \mathrm{C}$ & 188 & 4.30 & 1.69 & & $2.77(0.01)$ & $4.33(0.00)$ & \\
\hline $2 \mathrm{C}$ & $\mathrm{n}, \mathrm{J}$ & 219 & 4.75 & 1.62 & & & $1.48(0.14)$ & \\
\hline
\end{tabular}


Table 1: (continued)

\begin{tabular}{|c|c|c|c|c|c|c|c|c|}
\hline \multirow{2}{*}{$\begin{array}{l}\text { Question/ } \\
\text { aggregation } \\
\text { version }\end{array}$} & \multirow{2}{*}{$\begin{array}{c}\text { Framing } \\
\text { terms } \\
\text { used }\end{array}$} & \multirow[t]{2}{*}{$N$} & \multirow[t]{2}{*}{ Average } & \multirow[t]{2}{*}{ SD } & \multicolumn{4}{|c|}{$\begin{array}{l}T \text {-test statistic ( } p \text {-value) } \\
\text { compared to other versions }\end{array}$} \\
\hline & & & & & B & $\mathrm{C}$ & $\mathrm{D}$ & Combinations \\
\hline $2 \mathrm{D}$ & $\mathrm{i}, \mathrm{J}$ & 209 & 4.97 & 1.41 & & & & \\
\hline $2 \mathrm{~A} / 2 \mathrm{~B}$ & $\mathrm{C}$ & 372 & 4.33 & 1.67 & & & & $4.64(0.00)$ \\
\hline $2 \mathrm{C} / 2 \mathrm{D}$ & $\mathrm{J}$ & 428 & 4.86 & 1.53 & & & & \\
\hline $2 \mathrm{~A} / 2 \mathrm{D}$ & $\mathrm{i}$ & 393 & 4.69 & 1.56 & & & & $1.29(0.20)$ \\
\hline $2 \mathrm{~B} / 2 \mathrm{C}$ & $\mathrm{n}$ & 407 & 4.54 & 1.67 & & & & \\
\hline $3 \mathrm{~A}$ & SCS, o & 182 & 4.51 & 1.44 & $0.39(0.70)$ & $0.09(0.93)$ & $0.74(0.46)$ & \\
\hline $3 \mathrm{~B}$ & SCS, i & 224 & 4.46 & 1.41 & & $0.28(0.78)$ & $1.17(0.24)$ & \\
\hline $3 \mathrm{C}$ & $\mathrm{ES}, \mathrm{i}$ & 189 & 4.50 & 1.58 & & & $0.80(0.43)$ & \\
\hline $3 \mathrm{D}$ & $\mathrm{ES}, \mathrm{o}$ & 205 & 4.62 & 1.57 & & & & \\
\hline $3 \mathrm{~A} / 3 \mathrm{~B}$ & SCS & 406 & 4.48 & 1.43 & & & & $0.78(0.43)$ \\
\hline $3 \mathrm{C} / 3 \mathrm{D}$ & ES & 394 & 4.56 & 1.58 & & & & \\
\hline $3 \mathrm{~A} / 3 \mathrm{D}$ & o & 387 & 4.57 & 1.51 & & & & $0.91(0.36)$ \\
\hline $3 \mathrm{~B} / 3 \mathrm{C}$ & $\mathrm{i}$ & 413 & 4.47 & 1.49 & & & & \\
\hline $4 \mathrm{~A}$ & $\mathrm{ES}, \mathrm{K}$ & 229 & 4.90 & 1.62 & $0.02(0.99)$ & $0.32(0.75)$ & $0.47(0.64)$ & \\
\hline $4 \mathrm{~B}$ & $\mathrm{ES}, \mathrm{J}$ & 214 & 4.90 & 1.74 & & $0.32(0.75)$ & $0.44(0.66)$ & \\
\hline $4 \mathrm{C}$ & $\mathrm{SJ}, \mathrm{J}$ & 186 & 4.95 & 1.66 & & & $0.73(0.47)$ & \\
\hline $4 \mathrm{D}$ & SJ, K & 171 & 4.82 & 1.77 & & & & \\
\hline $4 \mathrm{~A} / 4 \mathrm{~B}$ & ES & 443 & 4.90 & 1.68 & & & & $0.09(0.93)$ \\
\hline $4 C / 4 D$ & SJ & 357 & 4.89 & 1.71 & & & & \\
\hline $4 \mathrm{~A} / 4 \mathrm{D}$ & K & 400 & 4.87 & 1.70 & & & & $0.48(0.63)$ \\
\hline $4 B / 4 C$ & $\mathrm{~J}$ & 400 & 4.92 & 1.70 & & & & \\
\hline
\end{tabular}

\section{Notes:}

$T$-tests utilised the non-assumption of equal variance between compared data. $p$-values are two-tailed. SD: standard deviation.

Framing term abbreviations:

C: $\quad$ Chinese

h: historical

J: Japanese/Japan

n: none (no adjective preceding "Chinese" or "Japanese")

o: $\quad$ originally

SJ: $\quad$ Sea of Japan
ES: $\quad$ East Sea

i: inherent

K: $\quad$ South Korea

NT: Northern Territories

SCS: $\quad$ South China Sea

SK: $\quad$ Southern Kurils

While the averages are perhaps modestly interesting, they are not the central concern here. Instead, and noted in Table 1's final remaining columns, $T$-tests compare means of answers to different question versions/ aggregations. These columns provide both the $T$-test statistic and the $T$-test $p$-value. So, for example, comparing the answers given for versions B and C on Question 1, the T-test statistic is 0.27 and the $p$-value is 0.79.p-values show whether the various question forms produced (statistically) significantly different answers. $T$-test $p$-values $<0.05$ mark statistical significance, in the 
present case indicating that the differing means for responses between the different versions likely represent real differences of opinions. ${ }^{11}$ In other words, the variation in framing between versions created different responses. On the other hand, $p$-values $>0.05$ mean we cannot be confident that the differing versions produced any (framing) effect. Here, the results are straightforward. Most terminological variations generated no framing effects. In other words, the subtle terminological distinctions (between East Sea and Sea of Japan, say, or "historic" and "inherent" territory) made little-tono difference to respondents. For Questions 1, 3, and 4, no terminological variations produced statistically different responses (no $T$-test $p$-values $<$ 0.05). Statistical significance exists only for Question 2, and only there when separating between versions using either "Chinese" or "Japanese" in the explanatory paragraph. ${ }^{12}$ That difference altered the average by nearly half a point or more in the various version/aggregation comparisons, approximately 4.35 vs. 4.85 . But overall, the presumed terminological frames did not matter much, at least within this study's communicative context.

\section{DISCUSSION}

Previous studies have demonstrated the power of frames to influence people's understandings. Yet the terminological frames tested here, among this audience, show few effects. Why? I believe the answer relates to the relationship between frames and discourses. Effective frames generate (often implicit) connections to and meaningfully represent broadly ranging discourses. One of the framing experiments among Israelis referred to above (in the Research Strategy and the Dynamics of Framing section) exposed participants to a twominute framing speech read by an actor - a speech that purposefully engaged culturally resonant rhetoric - before being tested on whether the framing impacted their political position (Zellman 2015). Non-experimental analyses typically also discuss framing's power in relation to relatively fully articulated frames (for example, Holden 2020; Wiegand 2005; Leitner and Strunk 2014; Sanderfer 2016; Goddard 2009; Hussein 2017). However, the current study minimally elaborated the potential frames in order to explore framing's limits. Thus, compared to other studies, the frames employed here likely did not send enough resonant signals to this audience of U.S.-Americans. Purcell, Heitmeier, and Van Wyhe produced the rare study examining the effects of minimally articulated frames; they focused on framing in jokes (Purcell et al. 2017). That study reminds readers of what comedians know intuitively: 
only a limited number of references are understood well enough by diverse audiences to produce laughs. Translated to framing, effective use of short terminology needs to draw on (already socially well-established) frames rather than expect such terminology to establish frames.

When a label or key adjective moves from its original audience to another, part of its framing power - the capacity to condense certain meanings and render them powerfully intelligible - weakens. East Sea or Sea of Japan, for instance, are entrenched terminological frames in East Asia (particularly in South Korea and Japan). Such appellations draw on and remind regional audiences of culturally ingrained debates and discourses. But when moved to a new interpretive landscape, such as the U.S., the frames no longer provide a reliable intertextual compass. The different audience likely does not discern, for another example, that "Northern Territories" signposts Japanese ownership of the island group. It does not find "inherent", by itself, to be a particularly intelligible, resonant, or powerful way to mark a territorial claim. Thus, I believe this study shows some of the limits of labels as framing devices within international politics. Partisans within disputes understandably attempt to express their positions and points of view powerfully and accurately when making appeals that extend beyond the debates' original settings. But, as these backers surely intuit, getting the terminology "right" is not the end of the process. Establishing meaningful discourses behind the terminological frames is also necessary for the frames to resonate effectively.

However, this study also highlights a second element of framing: its foregrounding. The survey's results suggest that it may not be difficult to create framing effects through foregrounding. To be sure, the most minimal phrases tested as terminological frames were not enough. But recall that the only statistically significant evidence of framing effects came with Question 2, specifically when "Chinese" and "Japanese" were substituted for one another. Why was this case different? Let us compare the two versions more directly. The "Chinese" version (with "inherent": Question 2A) reads:

Japan and China spar over small islands. China called on Japan to return several small islands located close to both the Okinawa Islands (Japanese territory) and Taiwan (claimed by China). China asserts the islands were stolen during Japan's 19th-20th century imperial expansion. The islands "are inherent Chinese territory", says the Chinese government. Japan counters that it claimed the uninhabited islands legitimately under international law. 
The "Japanese" version (Question 2D) is:

Japan and China spar over small islands. China called on Japan to return several small islands located close to both the Okinawa Islands (Japanese territory) and Taiwan (claimed by China). China asserts the islands were stolen during Japan's 19th-20th century imperial expansion. Japan counters that it claimed the uninhabited islands legitimately under international law. The islands "are inherent Japanese territory", says the Japanese government.

The sentence-order variation is likely irrelevant. Note, however, that switching a single term (twice) alters the tone of a whole sentence. Unlike the other cases, it is no longer just a single term-one obliquely referring to broader, perhaps little-known discourses - that differs. So, while a representation of both sides' positions exists in all versions of Question $2,{ }^{13}$ as in Questions 1 and 3, the use of either "Japanese" or "Chinese" unbalances the statements. It provides a straightforward, full-sentence support for only one or the other of the countries' positions. Now it is no longer just terminology that varies between versions, but also substantial content. This additional sentence focuses the (partisan) lens of the framing for the U.S.-American audience in a way that the study's other terminological frames do not. It presumably gives some readers a sense that their sympathies should lie more with one side of the territorial dispute than the other, despite the explanation being otherwise "balanced". This was not a change of large magnitude within the audience, but it has strong statistical significance. Thus, even short statements-at least for this not-strongly partisan audience - can easily produce framing effects within international politics. But these framing effects are not the automatic result of simply changing the labels. Additional discursive devices are required to more fully establish the frame.

\section{CONCLUSION}

The aim of this research was simple: to determine whether certain key toponyms or phrases used within eastern Asian international politics on their own, with minimal additional explanation, shape views outside the region towards key regional political disputes. Partisans often strongly emphasise what they regard as the correct or most effective versions of these phrases in their appeals to extra-regional audiences. Nevertheless, this study suggests that these labels, at least at times, do not by themselves create opinion-shaping 
framing effects. Calling the sea into which North Korea lobs its missiles the East Sea rather than the Sea of Japan seemingly changes little in how this U.S.-American audience regards those tests, for instance. Likewise, it is not clear that use of "inherent territory" over other alternatives strengthens the persuasiveness of territorial claims. Thus, in one important sense, the research identifies certain limits of these labels.

This is not to suggest, however, that these contests over nomenclature will be downplayed any time soon. Using the "correct" or most effective terminology continues to matter greatly within the region. The discourses that give the labels resonance as terminological frames operate strongly within eastern Asia. Even among a more international audience, the labels, though probably insufficient on their own, play important roles within wider framing and discursive strategies. ${ }^{14}$ Undoubtedly, few partisans believe that the labels by themselves are sufficiently persuasive. Their appeals internationally almost always also attempt to establish the broader discourses in addition to the terms. Those who use the phrases surely understand what this study has additionally shown - that it does not take much beyond minimally deploying these labels to shape opinions. All it took in Question 2 for clear effects (if modest in magnitude) was one extra sentence directly claiming territory for one or the other state.

The goal of this study has not been to determine whether framing affects viewpoints towards eastern Asia's international conflicts. Rather it started from a position well established within critical geopolitics: that, as part of broader discourses, framing is powerful. It then asked how little framing is necessary to affect a relatively non-involved audience's viewpoint. While this study identifies certain limits of terminological framing, further studies might build on and refine the findings here. Discourse and framing do not have universal effects. Research in critical geopolitics demonstrates that discursive formations shift over time in terms of which formulations are used and resonate most strongly (Glasze 2007). Not only that, but people respond differently to those formations depending on time, place, age, generation, gender, class, education, personal background, and so on (Benwell and Dodds 2011). One might expect the framing effects studied here to differ in different geographic and language contexts. Results obtained in the U.S. may not be identical to those that potential future research finds in Australia, the Philippines, France, India, Peru, or Indonesia, for example. ${ }^{15}$ Differing research designs could also more carefully examine whether social categories are associated with different responses to the frames. And though perhaps difficult through experimental surveys, creatively constructed research might ask whether the frame effects have changed through time. 
Even apart from the social and time-space variability of framing effects, further research could pursue how much additional discursive content among extra-regional audiences is needed before the labels start to operate as true (perspective affecting) frames. Within international politics, where are the boundaries between effective and non-effective framing? Larger samples and more finely tuned statements would help answer these questions. Will eastern Asia's increasing reliance on "inherent" have the desired effects, or are there more effective options, for example? Or how much more do people need to know before reference to Northern Territories or Southern Kurils affects their affinity towards one cause or the other? These and other possible questions demonstrate that there remains much to learn about the international implications of eastern Asia's territorial terminological frames.

\section{ACKNOWLEDGEMENTS}

Thanks to two very insightful reviewers' as well as editors' thoughts in sharpening this paper! I also want to acknowledge Chenoa Yorgason's helpful suggestions regarding setting up and performing the survey.

\section{COMPLIANCE WITH ETHICAL STANDARDS}

Survey participation was gained through informed consent of respondents in accordance with procedures standard in U.S. social science research.

\section{NOTES}

* Ethan Yorgason is an American political and cultural geographer working in South Korea who has also taught in the U.S. and Taiwan. His conceptual interests centre around geopolitics, place/region(alism)/nation(alism), and identity. Much of his recent research involves maritime issues in eastern Asia, but he has also published on varying topics including religion, tourism, ethnic settlement, and the mass media.

1 I use the lower-case formulation, "eastern Asia" (rather than the more common "East Asia") to signal that I have a more geographic than cultural sense in mind. "Eastern Asia" here covers (North)east and Southeast Asia.

2 This article concerns conflicts over seas and small islands, disputes often interlaced. Hereafter, I use "maritime" for the former, "territorial" for the latter, and both-as here-when referring to the two together.

3 As van Dijk (2016a: 11) notes, discourse analysis ideally involves deeply dissecting the semantics, rhetoric, and emphases surrounding certain social situations. As such, 
discourse analysis owes to much broader developments within more humanistic fields such as linguistics. Unfortunately, constructivism frequently overlooks those disciplines' contributions to such issues as micro-elements of sentence grammar within conversation and the contexts of communication.

4 This naming issue is actually even more complex, as additional terms exist. Taiwan, for example, has come to more typically label the islands as Diaoyutai.

5 North Korea's English-language website refers to this waterbody as the East Sea of Korea in full references, and East Sea in shorter references (The Democratic People's Republic of Korea 2011). Nevertheless, the DPRK has not been as active internationally in the naming dispute as the Republic of Korea (South Korea) has.

6 The opposition between these two studies is more apparent than real, even though I emphasise a bit of conceptual tension here. Among other things, the two deal with different contexts and impacts of framing: the first with differential framing of policy origins in order to create political understanding and agreement, the second with differential narrative framing around policies in order to create political mobilisation. For an example of more of a reconciliation of these ideas/processes, see Entman (2008: 93-94).

7 The test reveals whether there is a significant difference between obtained values (from the survey) and expected values (based on U.S. population characteristics). Chisquared test value $=4.91, p$-value $=0.556$ which exceeds the common $<0.05$ statistical significance threshold; thus, we cannot say that the sample is different from the U.S. population in this regional aspect. U.S. states were divided into seven regions based on geography and culture: Pacific (California, Oregon, Washington, Alaska, Hawaii), Intermountain West (Nevada, Idaho, Montana, Wyoming, Utah, Colorado, Arizona, New Mexico), Central (North Dakota, South Dakota, Nebraska, Iowa, Missouri, Kansas, Oklahoma, Texas), Great Lakes (Minnesota, Wisconsin, Illinois, Indiana, Michigan, Ohio, Pennsylvania), Lower South (Louisiana, Mississippi, Alabama, Florida, Georgia, South Carolina), Upper South (Arkansas, Tennessee, Kentucky, North Carolina, West Virginia, Virginia), and Northeast (Maryland, Delaware, New Jersey, New York, Connecticut, Rhode Island, Massachusetts, Vermont, New Hampshire, Maine). Comparison was to the U.S. Census's 2019 population estimates (United States Census Bureau 2019).

8 Perhaps the respondents' relatively high education level leads to greater sensitivity towards the framing variations, for example. Or it may lead to the opposite if the higher education allows respondents to see past the framing. Thus, if the demographic differences lead to differences in participants' (compared to U.S.-Americans generally) responses to the differently framed question versions of the questions, it is hard to predict what those differences might be.

9 This caption of the figure (and the caption for Figure 2) was not part of the survey. Only one of the two maps was used in each question version.

10 A question at the end of the survey sought to ensure that respondents completed the main questions with at least minimal care. More than $10 \%$ of initial responses failed to answer this "check" question correctly and were disqualified. The quick reading of the questions may, in some cases, be consistent with real-world exposure to these issues: unexplained labelling of the South China Sea or Sea of Japan in various media, for example, or quick or incomplete skimming of/listening to news stories reporting on 
"inherent" territory. In other cases, the quickness involved with this experiment may not adequately reflect people's exposure to the fuller, more detailed accounts available on these matters.

11 The null hypothesis of the $T$-test is that there is no difference in answers between the various question versions. Thus, $p<0.05$ means that the differences between means for the differing question-version samples are large enough to randomly occur less than $5 \%$ of the time if there is no true difference in answers between the questions. In other words, the likelihood is $95 \%$ or greater that there is a true difference in answers to the question versions. Conventionally, $p<0.05$ has marked the difference between significance and non-significance in much social science statistical research.

12 Statistically significant differences are thus found for: $2 \mathrm{~A}$ vs. $2 \mathrm{C}(p=0.020), 2 \mathrm{~A}$ vs. $2 \mathrm{D}$ (0.000), $2 \mathrm{~B}$ vs. $2 \mathrm{C}(0.006), 2 \mathrm{~B}$ vs. $2 \mathrm{D}(0.000)$, and $2 \mathrm{~A} / 2 \mathrm{~B}$ vs. $2 \mathrm{C} / 2 \mathrm{D}(0.000)$. Possible difference $(p=0.198)$ in how Question 2 was answered based on "inherent territory" rather than just "territory" may also be worth further exploration $(2 \mathrm{~A} / 2 \mathrm{D}$ vs $2 \mathrm{~B} / 2 \mathrm{C})$.

13 Both historical and geographical arguments for each side are implicit in each version of Question 2.

14 If Entman's (2008: 89) suspicion about U.S. public diplomacy - that states are more concerned with persuading elites than general publics internationally-is generalisable, it may be worth exploring whether the framing effects that apply to ordinary citizens (such as in this study) differ from the effects on elites, or even other groups such as U.S.-Americans who are in or have visited eastern Asia.

15 Studying other samples of U.S. citizens would also help confirm or question this study's results.

\section{REFERENCES}

Agnew, J. 2009. Globalization and sovereignty. Lanham, Maryland: Rowman \& Littlefield. Amer, R. 2014. China, Vietnam, and the South China Sea: Disputes and dispute management. Ocean Development and International Law 45 (1): 17-40. https://doi.org/10.1080/ 00908320.2013 .839160

Benford, R. D. and Snow, D. A. 2000. Framing processes and social movements: An overview and assessment. Annual Review of Sociology 26: 611-639. https://doi. org/10.1146/annurev.soc.26.1.611

Benwell, M. C. and Dodds, K. 2011. Argentine territorial nationalism revisited: The Malvinas/Falklands dispute and geographies of everyday nationalism. Political Geography 30 (8): 441-449. https://doi.org/10.1016/j.polgeo.2011.09.006

Bukh, A. 2010. Japan's national identity and foreign policy: Russia as Japan's 'other'. London: Routledge. https://doi.org/10.4324/9780203883754

Burghardt, A. F. 1973. The bases of territorial claims. Geographical Review 63 (2): 225245. https://doi.org/10.2307/213412

Burrett, T. 2014. Reaffirming Russia's remote control: Exploring Kremlin influence on television coverage of Russian-Japanese relations and the Southern Kuril Islands territorial dispute. Demokratizatsiya 22 (3): 359-381. 
Elden, S. 2010a. Land, terrain, territory. Progress in Human Geography 34: 799-817. https://doi.org/10.1177/0309132510362603

2010b. Thinking territory historically. Geopolitics 15 (4): 757-761. https://doi. org/10.1080/14650041003717517

Entman, R. M. 2008. Theorizing mediated public diplomacy: The U.S. Case. The International Journal of Press/Politics 13 (2): 87-102. https://doi. org/10.1177/1940161208314657

Fillmore, C. J. 1976. Frame semantics and the nature of language. In Origins and Evolution of Language and Speech, eds. Harnad, S. R., Steklis, H. D. and Lancaster, J. New York: Annals of the New York Academy of Sciences, 280(1), 20-32. https://doi. $\operatorname{org} / 10.1111 /$ j.1749-6632.1976.tb25467.x

Glasze, G. 2007. The discursive constitution of a world-spanning region and the role of empty signifiers: The case of Francophonia. Geopolitics 12 (4): 656-679. https:// doi.org/10.1080/14650040701546103

Goddard, S. E. 2009. When right makes might: How Prussia overturned the European balance of power. International Security 33 (3): 110-142. https://doi.org/10.1162/ isec.2009.33.3.110

Goffman, E. 1974. Frame analysis: An essay on the organization of experience. Cambridge, MA: Harvard University Press.

Goodby, J. E., Ivanov, V. I. and Shimotamai, N., eds. 1995. "Northern Territories" and beyond: Russian, Japanese, and American perspectives. Westport, CT: Praeger.

Holden, P. 2020. Territory, geoeconomics and power politics: The Irish government's framing of Brexit. Political Geography 76: 102063. https://doi.org/10.1016/j. polgeo.2019.102063

Hope, M. 2011. Frame analysis as a discourse-method: Framing climate change politics. Paper presented at the Post-Graduate Conference on Discourse Analysis, University of Bristol, Bristol, March 2010. https://www.academia.edu/306273/Frame Analysis_as_a_Discourse_Method_Framing_Climate_Change_Politics?email_ work_card=reading-history (accessed 10 October 2020).

Hussein, J. W. 2017. Frame analysis of the politics of identity and conflict at territorial frontiers: The case of Jarso-Girhi in Eastern Ethiopia. African Identities 15 (1): 79-99. https://doi.org/10.1080/14725843.2016.1175921

Hydrographic and Oceanographic Department, Japan Coast Guard. n.d. Japanese basic position on the naming of the "Japan Sea". https://www1.kaiho.mlit.go.jp/ GIJUTSUKOKUSAI/nihonkai/position_eng.htm (accessed 9 October 2020).

Inwood, J. and Bonds, A. 2016. Confronting white supremacy and militaristic pedagogy in the U.S. settler colonial state. Annals of the Association of American Geographers 106 (3): 521-529. https://doi.org/10.1080/24694452.2016.1145510

Ives, M. 2017. China cancels military meeting with Vietnam over territorial dispute. New York Times, 21 June 2017. https://www.nytimes.com/2017/06/21/world/asia/chinavietnam-south-china-sea.html (accessed 9 October 2020).

Johnson, J. 2017. China air force chief rips defense white paper, says "Sea of Japan is not Japan's". The Japan Times, 11 August 2017. https://www.japantimes.co.jp/ news/2017/08/11/national/politics-diplomacy/china-air-force-chief-rips-defensewhite-paper-says-sea-japan-not-japans/ (accessed 8 October 2020). 
Jones, R. 2012. Spaces of refusal: Rethinking sovereign power and resistance at the border. Annals of the Association of American Geographers 102 (3): 685-699. https://doi. org/10.1080/00045608.2011.600193

Kim, J. 2017. Disputed waters, contested norms: Framing discourses on the South China Sea disputes. Pacific Affairs 90 (2): 297-305. https://doi.org/10.5509/2017902297

Lee, K. G. 2015. An enquiry into the palimpsestic nature of territorial sovereignty in East Asia - with particular reference to the Senkaku/Diaoyudao question. In Sovereignty, statehood and state responsibility: Essays in honour of James Crawford, eds. Chinkin, C. and Baetens, F., 126-143. Cambridge, England: Cambridge University Press. https://doi.org/10.1017/CBO9781107360075.011

Leitner, H. and Strunk, C. 2014. Spaces of immigrant advocacy and liberal democratic citizenship. Annals of the Association of American Geographers 104 (2): 348-356. https://doi.org/10.1080/00045608.2013.875806

Luukkonen, J. and Sirviö, H. 2019. The politics of depoliticization and the constitution of city-regionalism as a dominant spatial-political imaginary in Finland. Political Geography 73: 17-27. https://doi.org/10.1016/j.polgeo.2019.05.004

Maoz, I., Ward, A., Katz, M. and Ross, L. 2002. Reactive devaluation of an "Israeli" vs. "Palestinian" peace proposal. Journal of Conflict Resolution 46 (4): 515-546. https://doi.org/10.1177/0022002702046004003

Maoz, I., Yaniv, I. and Ivri, N. 2007. Decision framing and support for concessions in the Israeli-Palestinian conflict. Journal of Peace Research 44 (1): 81-91. https://doi. org/10.1177/0022343307071496

Mitchell, T. 1990. Everyday metaphors of power. Theory and Society 19: 545-577. https:// doi.org/10.1007/BF00147026

Murphy, A. B. 2010. Identity and territory. Geopolitics 15 (4): 769-772. https://doi. org/10.1080/14650041003717525

Murphyao, A. and Black, K. 2015. Unsettling settler belonging: (Re)naming and territory making in the Pacific Northwest. American Review of Canadian Studies 45 (3): 315-331. https://doi.org/10.1080/02722011.2015.1063523

Okuda, H. 2014. Historical narratives in Japanese school textbooks. In The dispute over the Senkaku/Diaoyu Islands: How media narratives shape public opinion and challenge the global order, ed. Hollihan, T. A., 51-79. New York: Palgrave Macmillan. https://doi.org/10.1057/9781137443366_3

Olarte-Olarte, M. C. 2019. From territorial peace to territorial pacification: Anti-riot police powers and socio-environmental dissent in the implementation of Colombia's peace agreement. Revista de Estudios Sociales 67: 26-39. https://doi.org/10.7440/ res67.2019.03

Pain, R. 2015. Intimate war. Political Geography 44: 64-73. https://doi.org/10.1016/j. polgeo.2014.09.011

Pain, R. and Staeheli, L. 2014. Introduction: Intimacy-geopolitics and violence. Area 46 (4): 344-347. https://doi.org/10.1111/area.12138

Purcell, D., Heitmeier, B. and Van Wyhe, C. 2017. Critical geopolitics and the framing of the Arab Spring through late-night humor. Social Science Quarterly 98 (2): 513531. https://doi.org/10.1111/ssqu.12296 
Roszko, E. 2015. Maritime territorialisation as performance of sovereignty and nationhood in the South China Sea. Nations and Nationalism 21 (2): 230-249. https://doi. org/10.1111/nana.12094

Ryu, J. H. 2012. Postcolonial urbanization and changes of vernacular toponyms around Bupyeong-gu, Incheon: A critical perspective. Korea Journal 52 (1): 140-170. https://doi.org/10.25024/kj.2012.52.1.140

Sage, D. 2008. Framing space: A popular geopolitics of American manifest destiny in outer space. Geopolitics 13 (1): 27-53. https://doi.org/10.1080/14650040701783482

Sanderfer, S. 2016. Interracial cooperation and strategic framing in 19th-century southern black emigration movements. Journal of the Indiana Academy of the Social Sciences 19 (1): 129-154.

Schoenbaum, T. J., ed. 2008. Peace in Northeast Asia: Resolving Japan's territorial and maritime disputes with China, Korea and the Russian Federation. Cheltenham, UK: Edward Elgar Publishing.

The Democratic People's Republic of Korea. 2011. Korean Friendship Association. https:// www.korea-dpr.com/location.html (accessed 5 January 2021).

The Government of Japan. 2019. "Sea of Japan", the one and only internationally established name. https://www.japan.go.jp/tomodachi/2019/spring2019/sea_of_japan.html (accessed 9 October 2020).

The Ministry of Foreign Affairs of Japan. 2017. The issue of name "Sea of Japan", 7 February. https://www.mofa.go.jp/policy/maritime/japan/index.html (accessed 8 October 2020).

The Society for East Sea. 2014. Why "East Sea". http://eastsea1994.org/eng/html/easts eastsea.php?ckattempt $=1$ (accessed 8 October 2020).

United States Census Bureau. 2019. 2019 National and state population estimates (NSTEST2019-01: Table 1. Annual estimates of the resident population for the United States, regions, states, and Puerto Rico: April 1, 2010 to July 1, 2019). https://www. census.gov/newsroom/press-kits/2019/national-state-estimates.html (accessed 10 October 2020).

Van Dijk, T. A. 2016a. Analyzing frame analysis: A critical review of framing studies in social movement research. Working paper version 4.0, 2 December. https:// www.academia.edu/40286423/Analyzing_Frame_Analysis_A_Critical_Review_ of_Framing_Studies_in_Social_Movement_Research?email_work_card=readinghistory (accessed 10 October 2020).

. 2016b. Social movements, frames and discourse: A critical review. Working paper version 1.0, December. https://www.academia.edu/40286424/Social_Movements_ Frames_and_Discourse_A_Critical_Review (accessed 10 October 2020).

Vollaard, H. 2009. The logic of political territoriality. Geopolitics 14 (4): 687-706. https:// doi.org/10.1080/14650040903141356

Voluntary Agency Network of Korea. n.d. Why is the East Sea not the Sea of Japan? http://whyeastsea.prkorea.com/why-east-sea-not-sea-of-japan/ (accessed 7 October 2020).

$\mathrm{Vu}$, P. 2020. Vietnam welcomes rejection of China's East Sea claims. VN Express International, 15 July. https://e.vnexpress.net/news/news/vietnam-welcomesrejection-of-china-s-east-sea-claims-4131035.html (accessed 9 October 2020). 
Wada, H. 2013. How to solve East Asia's territorial problems (동북아시아 영토문제, 어떻게 해결할 것인가), Korean trans. of 2012 Japanese original, Gyeong-taek Lim (임경택). Paju, South Korea: Sanyejul Publishing.

Walsh, C. 2014. Rethinking the spatiality of spatial planning: Methodological territorialism and metageographies. European Planning Studies 22 (2): 306-322. https://doi.org/ 10.1080/09654313.2012.741568

Wang, G. 2017. Discursive construction of territorial disputes: Foreign newspaper reporting on the Diaoyu/Senkaku Islands dispute. Social Semiotics 27 (5): 567-585. https:// doi.org/10.1080/10350330.2017.1292621

Wellisch, S. and Laš, L. 2020. Media discourses of territorial disputes in Japan. Asian Geographer. https://doi.org/10.1080/10225706.2020.1768569

Whelen, Y. 2011. (Inter)national naming: Heritage, conflict and diaspora. ACME: An International E-Journal for Critical Geographies 10 (1): 7-12.

Wiegand, K. E. 2005. Nationalist discourse and domestic incentives to prevent settlement of the territorial dispute between Guatemala and Belize. Nationalism and Ethnic Politics 11 (3): 349-383. https://doi.org/10.1080/13537110500255486

Wilde, R. 2004. Representing international territorial administration: A critique of some approaches. European Journal of International Law 15 (1): 71-96. https://doi. org/10.1093/ejil/15.1.71

Winichakul, T. 1994. Siam mapped: A history of the geo-body of a nation. Honolulu: University of Hawai' $i$ Press.

Wirth, C. 2016. Securing the seas, securing the state: Hope, danger, and the politics of order in the Asia-Pacific. Political Geography 53: 76-85. https://doi.org/10.1016/j. polgeo.2016.02.002

Yi, S. 2014. The geopolitics of seas and the cartography of naming seas: The name "Sea of Japan" reflecting an imperialist ideology. Asia Pacific Journal of Marine Science and Education 4 (1): 29-43.

Yorgason, E. 2018. International political implications of language: The linguistic puzzle of "inherent territory". The Korean Journal of International Studies 16 (3): 435466. https://doi.org/10.14731/kjis.2018.12.16.3.435

. 2017. Eastern Asia's revitalization of the state ideal through maritime territorial disputes. Political Geography 61: 203-214. https://doi.org/10.1016/j. polgeo.2017.09.012

Zacher, M., Brehm, H. N. and Savelsberg, J. J. 2014. NGOs, IOs, and the ICC: Diagnosing and framing Darfur. Sociological Forum 29 (1): 29-51. https://doi.org/10.1111/ socf. 12068

Zellman, A. 2015. Framing consensus: Evaluating the narrative specificity of territorial indivisibility. Journal of Peace Research 52 (4): 492-507. https://doi. org/10.1177/0022343314564713 